\title{
Recent records of Tapirella bairdii and Panthera onca in a region highly transformed by human activities in southern Veracruz, México
}

\author{
Roldan Vivas-Lindo', Omar Hernández-Ordóñez ${ }^{2 *}$, Miguel A. Rodriguez-Salazar², Víctor H. Reynoso², and Ricardo Serna-Lagunes ${ }^{1}$ \\ 1 Unidad de Manejo y Conservación de Recursos Genéticos. Facultad de Ciencias Biológicas y Agropecuarias, región Orizaba- \\ Córdoba. Universidad Veracruzana. Josefa Ortiz de Domínguez S/N, 94945,Veracruz. Veracruz, México. Email:vivaslindoroldan@ \\ gmail.com (RV-L), rserna@uv.mx (RS-L). \\ 2 Departamento de Zoología, Instituto de Biología, Universidad Nacional Autónoma de México, 04500, Ciudad Universitaria. \\ Ciudad de México, México. Email: miguel angel@ciencias.unam.mx (MAR-S) omar.hernandez@ib.unam.mx (OH-O), vreynoso@ \\ ib.unam.mx (VHR). \\ *Corresponding author
}

The tapir (Tapirella bairdii) and the jaguar (Panthera onca) are two of the largest Neotropical mammal species suffering population declines caused by habitat loss and degradation and hunting. Tapirs and jaguars are considered endangered and near threatened, respectively, by the IUCN, and in Mexico, both species are listed as endangered and considered species with priority for conservation. These species are usually associated with large and remote areas of preserved forest. To evaluate local diversity of medium and large sized mammals, we placed five camera traps, three in old forest and two in secondary forest (445 trap days) at Ejido Ramos Millán (municipality of Minatitlán), on the northernmost part of the Uxpanapa Valley, in the Gulf of Mexico coastal plain, state of Veracruz, Mexico. This region has been highly transformed by human activities, where agricultural and livestock activities have caused the loss of most of its natural forests, resulting in a highly fragmented landscape, dominated by livestock fields, crops and secondary forests. Here we document images of three adult individuals of jaguar and two adult individuals of tapir, one of which was a lactating female, and one adult male tapir. The new records were $23 \mathrm{Km}$ north of the most recent reports located in well preserved primary forests in the Uxpanapa/Chimalapas border area. Our results suggest that the highly fragmented tropical landscapes composed of both old-growth and secondary forests remnants, are able to provide sufficient resources to maintain at least temporarily individuals of jaguars and tapirs.

El tapir (Tapirella bairdii) y el jaguar (Panthera onca) son dos de las especies de mamíferos neotropicales más grandes en México, Centro y Sudamérica. A lo largo de su distribución, sufren una disminución poblacional causada por la pérdida y degradación del hábitat y la caza. El tapir y jaguar son considerados en peligro y casi amenazados, respectivamente, por la UICN, y en México, ambas especies están consideradas en peligro de extinción y se consideran especies prioritarias para la conservación. Estas especies generalmente se asocian a grandes y remotas extensiones de bosque preservado. Para evaluar la diversidad local de mamíferos medianos y grandes, colocamos cinco fototrampas, tres en fragmentos de bosque viejo y dos en bosques secundarios (445 días trampa) en el Ejido Ramos Millán (municipio de Minatitlán), en la parte más al norte del valle de Uxpanapa, en la planicie costera del Golfo de México, estado de Veracruz, México. Esta región ha sido altamente modificado por las actividades humanas, en donde las actividades agrícolas y ganaderas han causado la pérdida de la mayoría de los bosques naturales, resultando en un paisaje fragmentado, dominado por pastizales ganaderos, cultivos y bosques secundarios. Aquí documentamos imágenes de tres individuos adultos de jaguar y dos individuos adultos de tapir, uno de los cuales era una hembra lactante y un tapir macho adulto. Los nuevos registros se localizaron $23 \mathrm{Km}$ al norte de los registros más recientes ubicados en bosques primarios bien conservados en el área fronteriza de Uxpanapa/Chimalapas. Nuestros resultados sugieren que los paisajes tropicales altamente fragmentados, compuestos por fragmentos de bosque viejo y secundario, son capaces de proporcionar recursos suficientes para mantener al menos temporalmente individuos de jaguares y tapires.

Keywords: camera trap; jaguar; old forest fragments; secondary forests; tapir; tropical rain forest.

(c) 2020 Asociación Mexicana de Mastozoología, www.mastozoologiamexicana.org

\section{Introduction}

Tapirs (Tapirella bairdii) and jaguars (Panthera onca) are two of the most threatened large terrestrial mammals in the Neotropics (Quigley et al. 2017; García et al. 2016). Both species are considered "endangered" and "near threatened", respectively, by the IUCN. In Mexico, they are listed as "endangered" (SEMARNAT 2010) due to habitat loss, habitat modification, and hunting (Chávez-Tovar et al. 2005; March and Naranjo 2005). Although historic distribution of both species extended over a broad distributional area (ChávezTovar et al. 2005; March and Naranjo 2005), local populations have been drastically reduced in most parts of the country (Chávez-Tovar et al. 2005; March and Naranjo 2005; Naranjo 2009; Chávez-Tovar et al. 2016). Because of their status as endangered species, the Mexican government has considered jaguars and tapirs as priority species for conservation (García et al. 2016; Quigley et al. 2017).

In southeastern Mexico, both jaguars and tapirs have been recently reported in tropical rainforests, tropical dry forests and cloud forests, along the states of Veracruz, Oaxaca, Chiapas, Tabasco, Campeche, Yucatán, and Quintana Roo (Chávez-Tovar et al. 2005; Naranjo 2009). However, the distribution of tapirs is more restricted, and no recent records have been reported in Tabasco and Yucatán (March 
and Naranjo 2005). Currently, both species still have relatively high population sizes in large forest fragments of difficult access, low human presence, and with some degree of protection (e. g., Los Chimalapas and Sierra Norte in Oaxaca, Sierra Madre de Chiapas and Lacandona in Chiapas, Calakmul in Campeche and Sian Ka'an in Quintana Roo; Naranjo 2009; Chávez-Tovar et al. 2016; Botello et al. 2017). However, Chávez-Tovar et al. (2016) and Luja et al. (2017) indicated that jaguars may occur in unprotected or highly fragmented sites with human impact. Also, the two species play important roles in the ecosystem; tapirs are important herbivores and seed dispersers of various plant species (Naranjo 2009), and jaguars are the largest predators in the Neotropics (Chávez-Tovar et al. 2005).

Although jaguars and tapirs were historically distributed across the Coastal Plain of the state of Veracruz, in the northern portion of the Isthmus of Tehuantepec (ChávezTovar et al. 2005; March and Naranjo 2005), both species are thought to be nearly extirpated from the area (March and Naranjo 2005; SEMARNAT 2009), particularly, in the Uxpanapa valley, where livestock and agricultural activities have caused high deforestation rates since the 1970s (Ellis et al. 2011). For example, in Las Choapas and Minatitlán the forest cover decreased $17 \%$ and $14 \%$, respectively, between 2001 and 2017 (Global Forest Watch 2018). In addition, this area has important petrochemical complexes, causing high pollution levels (Espinosa-Reyes et al. 2013). The most recent records for both species in Veracruz have been documented at most $10 \mathrm{~km}$ north from the Uxpanapa/Chimalapas border where the largest remnant of tropical rainforest in Mexico still exists, and it is believed that large viable populations of these two species still exist (Lira-Torres et al. 2014; Naranjo et al. 2015).

Local efforts by inhabitants in the Uxpanapa valley have promoted the regeneration and conservation of large extensions of secondary and old forest fragments. With these efforts, natural forest regeneration appears to provide suitable environmental conditions and resources that are already promoting the return of large mammals. Here we reported the presence of jaguar and tapir in sites previously unsampled with camera traps, in the northern portion of the Uxpanapa valley, being the most recent records of these two species in the municipality of Minatitlán.

\section{Materials and methods}

Study site. Sampling was done in tropical rain forest remnants in the Ejido Gabriel Ramos Millán (17 22' 21.75" N, $-94^{\circ} 10^{\prime} 33.68^{\prime \prime} \mathrm{W}$ ), Municipality of Minatitlán, located on the upper northern limits of the Uxpanapa valley (southeastern Veracruz; Figure 1a, b). The original vegetation in the region was tropical rainforest extended along plains, soft hills and ravines (Hernández et al. 2013); but in the last 40 years, changes in land use derived from agricultural and livestock activities, and the large fire occurred in 1998, destroyed more than $70 \%$ of the original vegetation cover (Hernández et al. 2013).
Sampling. We conducted two sampling seasons, the first from July to October 2018 and the second from December 2018 to April 2019. We set five camera stations with one camera trap each (Cuddeback ${ }^{\oplus}$, Bushnell ${ }^{\circledast}$ and Wildgame ${ }^{\circledast}$ ). Three stations were placed in two old growth forest fragments as followed: Station 1 ( $17^{\circ} 22^{\prime} 23.38^{\prime \prime} \mathrm{N},-94^{\circ} 13^{\prime} 48.25^{\prime \prime}$ W, 117 masl), placed in a 380 ha fragment of old growth forest surrounded by a $>10,000$ ha large fragment of secondary forest; Station 2 ( $17^{\circ} 20^{\prime} 56.05^{\prime \prime} \mathrm{N},-94^{\circ} 10^{\prime} 1.90^{\prime \prime} \mathrm{W}, 74$ masl), placed in a 220 ha old-growth forest fragment surrounded by secondary forests and cattle pastures; and Station $3\left(17^{\circ}\right.$ $21^{\prime} 06.37^{\prime \prime} \mathrm{N},-94^{\circ} 11^{\prime} 35.98^{\prime \prime} \mathrm{W}, 120$ masl), placed in a 149 ha old-growth forest fragment surrounded by secondary forests and cattle pastures. Two more stations were placed in a 20-year secondary forests: Station $4\left(17^{\circ} 21^{\prime} 30.5^{\prime \prime} \mathrm{N},-94^{\circ} 10^{\prime \prime}\right.$ $\left.06.3^{\prime \prime} \mathrm{W}, 37 \mathrm{masl}\right)$, placed in a forest fragment of $160 \mathrm{ha}$; and, Station $5\left(17^{\circ} 20^{\prime} 45.5^{\prime \prime} \mathrm{N},-94^{\circ} 09^{\prime} 07.7^{\prime \prime} \mathrm{W}, 68\right.$ masl), placed in a forest fragment of 166 ha (Figure 1c).

Camera traps were set at least $1.0 \mathrm{Km}$ away from each other (1.6 Km on average) on natural paths, between 50 to $60 \mathrm{~cm}$ height on tree trunks (Lira-Torres et al. 2014; BrionesSalas et al. 2016). Every camera trap was georeferenced using a Garmin, Etrex ${ }^{\circledast} 20 x$ global positioning system (GPS). The sampling effort was calculated in trap-days by multiplying the total number of camera traps set by the total number of days cameras were active (Briones-Salas et al. 2016), totaling 1,005 trap-days (445 trap-days between July and October, 2018, and 560 trap-days between December 2018 and April 2019). All images were deposited in the Phototrap Collection at the Institute of Biology, Universidad Nacional Autónoma de México, and are available for request.

\section{Results}

Of the five stations, four (stations 1, 2, 4 and 5) recorded individuals of jaguars (two stations) or tapirs (three stations) during the two sampling seasons: In station 1, in the first sampling season (between July 28 and August 31, 2018), we recorded 18 images and 10 independent events of two adult jaguars (Figure 2a, b). In the second sampling season (between December 24, 2018 and January 25, 2019), we recorded 10 images and 9 independent events of one adult jaguar. In station 2, in the first sampling season, we recorded one image of an adult jaguar on July 27,2018 , and an adult tapir in two independent events, the first on July 31, 2018 (Figure 2c), and the second in September 10, 2018. During the second sampling season (between December 26, 2018 and April $2^{\text {nd }}, 2019$ ), we recorded 11 images and eight independent records of an adult tapir. In station 4, in the first sampling season, we recorded one adult tapir in two independent events, the first on August $11^{\text {th }}, 2018$, and the second in October $6^{\text {th }}, 2018$ (Figure 2d). In the second sampling season (between December 25, 2018 and March $9^{\text {th }}, 2019$ ), we recorded 11 images and four independent events of an adult tapir. In station 5, during the first sampling season (between August 11 and September $3^{\text {rd }}$, 2018), we recorded 64 images in 12 independent events of 


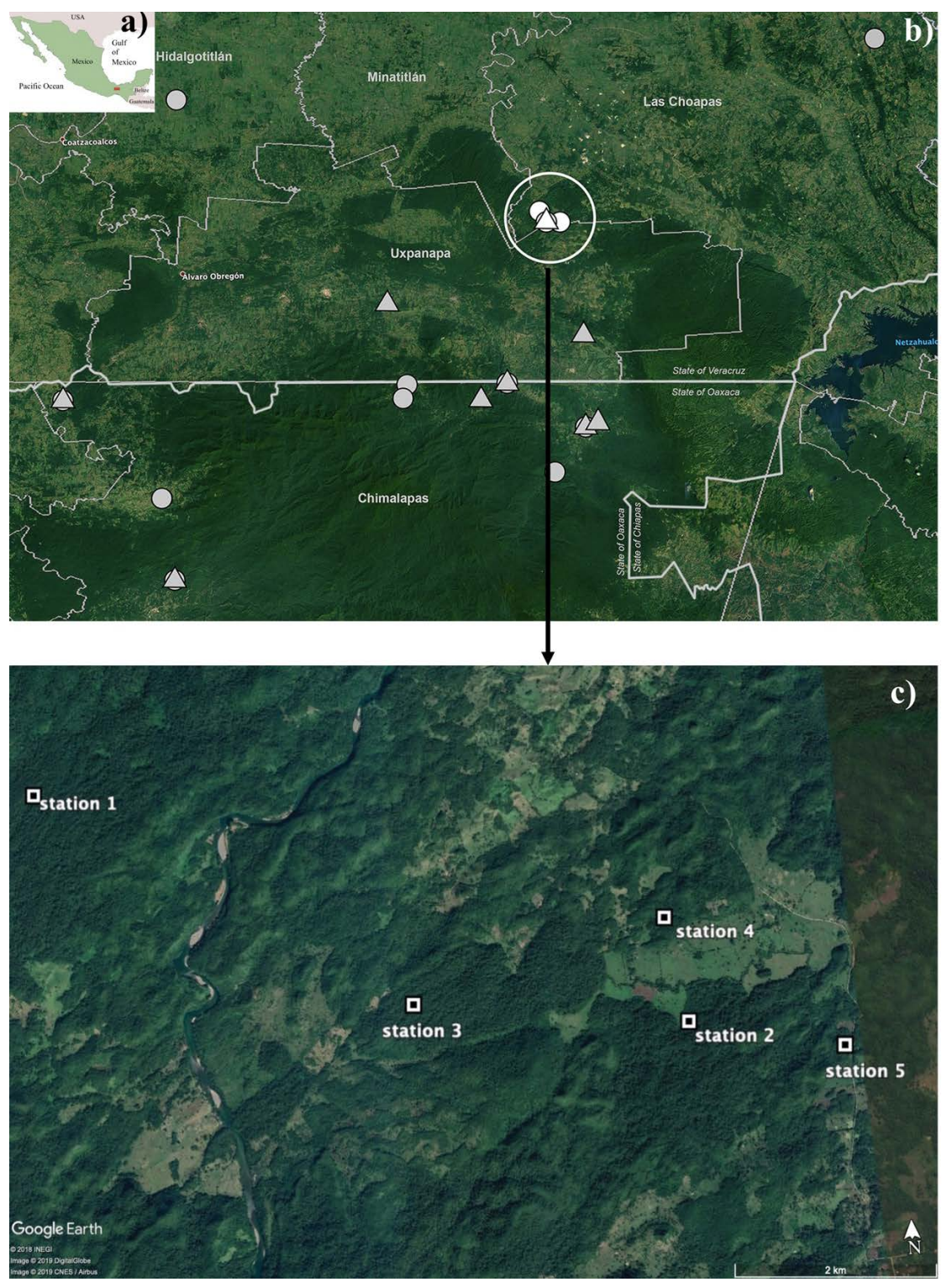

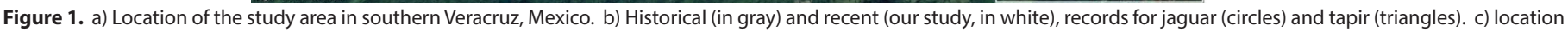
of the five camera stations within the "Ejido Ramos Millán", municipality of Minatitlán, Veracruz, Mexico.

adult tapirs. During the second sampling season (between December 23, 2018 and January $3^{\text {rd }}, 2019$ ), we recorded 27 images and three independent events of two adult tapirs (female and male). In many photographs it was possible to see that one tapir was a lactating female (Figure 2e), and in one video recorded in March 3rd, 2018, we documented an adult male (Figure $2 \mathrm{f}$ ).

\section{Discussion}

Jaguars have been rarely recorded in the Uxpanapa valley. Only three records have been reported between 1990 to 2008 in three different sites, one located at approximately 50 $\mathrm{km}$ northeast, one $50 \mathrm{~km}$ northwest, and one $20 \mathrm{~km}$ south of our study site, between the Chimalapas/Uxpanapa border (Briones-Salas et al. 2016; Rodríguez-Soto et al. 2011). Our record represents the first record in the last 10 years in the Uxpanapa valley and the first historical record of the species in the municipality of Minatitlán, where the jaguar was considered already extirpated (SEMARNAT 2009). Jaguars are normally recorded in localities immersed in or connected to dense tropical forests (Chávez-Tovar et al. 2005). We believe that jaguars recorded here were not only in-transit dispersing individuals from nearby large preserved forests (e. g., Chimalapas region), but animals residing in the site. In station 1 , the same individual was photographed several days during the two sampling seasons along eight months, which suggests the old-growth forest fragment is part of its territory. Considering the size of the fragment where station 1 was set ( $>10,000$ ha, including secondary and old forest). We believe that this fragment can either work as a biological corridor or as a stepping-stone habitat (Luja et al. 2017), where jaguars can be established temporarily or even permanently. During our survey we abundantly recorded three main jaguar preys, the nine-banded armadillo (Dasypus novemcinctus), whitenosed coati (Nasua narica) and the collared peccary (Pecari tajacu; Chávez-Tovar et al. 2005). Additionally, the presence of karstic caves in the region may provide permanent refuge to jaguars (Chávez-Tovar et al. 2005). 
Before our study, the last tapir records (2003-2015) were located not more than $10 \mathrm{~km}$ away from the border of the Chimalapas/Uxpanapa forest, which harbors one of the most important tapir populations in Mexico (Lira-Torres et al. 2014). However, our record extends as far as $22.5 \mathrm{~km}$ straight line to the north from "La Fortaleza" in Chimalapas, Oaxaca, into Minatitlán, Veracruz. Residents of Ejido Gabriel Ramos Millán indicated that tapir sightings began to occur approximately seven years ago (2011) in lowlands, floodplains and temporary streams. We believe that tapirs were already established within the forest remnants by the time camera-traps were placed. This is supported by the high frequency of independent photograps of individuals, the presence of adult tapirs of both sexes, and the record of a breeding female.
Secondary forests are the dominant component of lowland landscapes in the Neotropics (Melo et al. 2013). Much has been discussed about the importance of secondary forest for the conservation of biodiversity (Melo et al. 2013). Our records of jaguars and tapirs in human modified habitats suggest that local conservation efforts by the Ramos Millán people, preserving old growth and secondary forest in a fragmented landscape, have allowed the return of large mammals in sites where they were already extirpated. These species have been scarcely recorded in fragmented landscapes (e. g., Marqués de Comillas region, Lacandona rainforest, Chiapas) as they prefer large fragments (at least 1,000 ha) of old-growth forest (Muench and Martínez-Ramos 2016). It has been documented

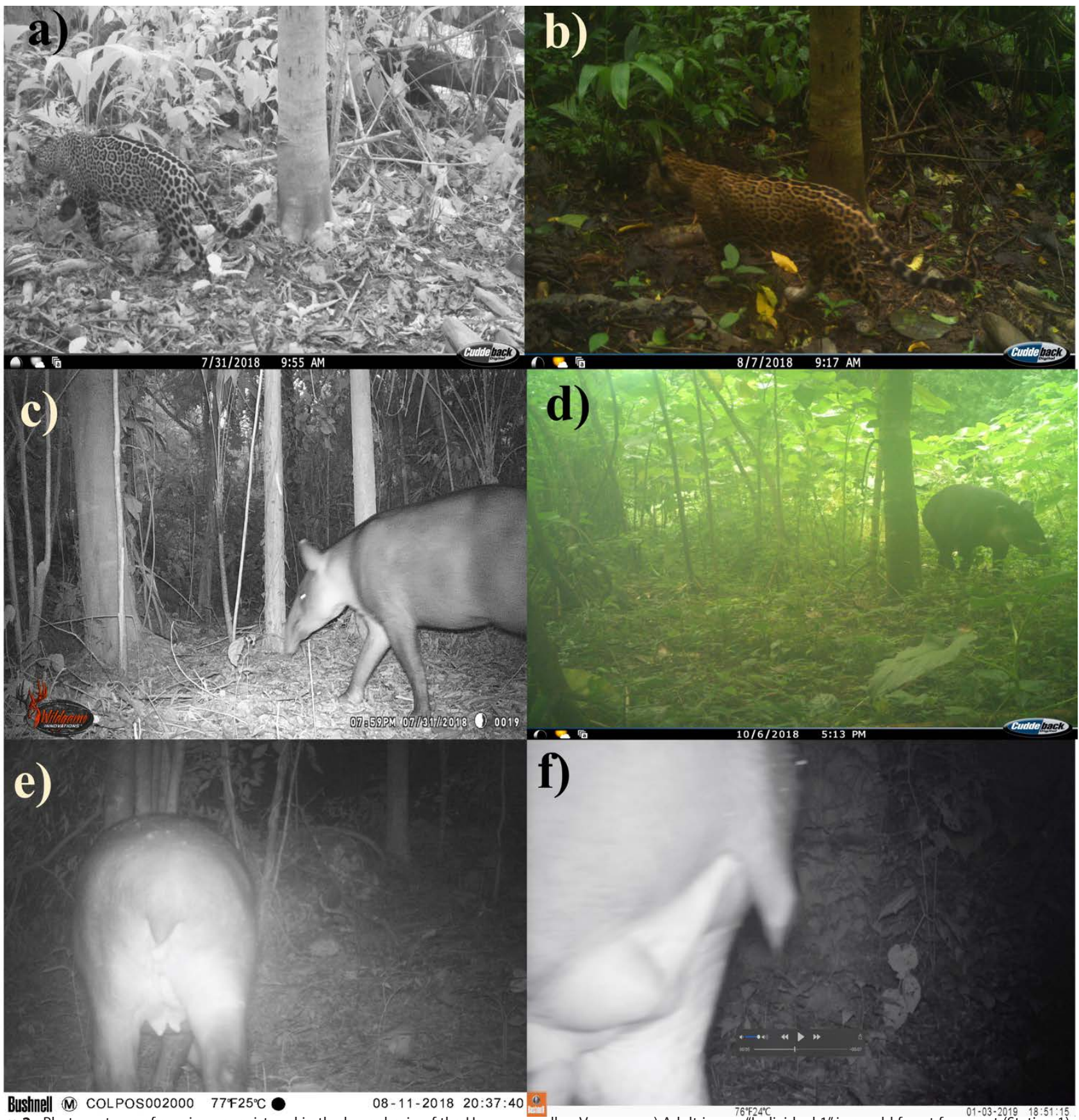

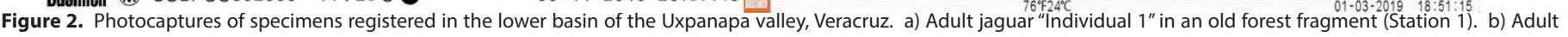

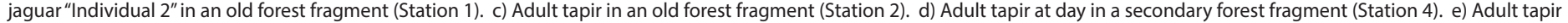
female (Station 4). f) Adult tapir male (Station 4). 
that in natural protected areas with large forested fragments, tapirs prefer sites with abundant water (streams and swamps) and with secondary vegetation dominated by edible species (Naranjo 2009). It is likely that the collective decision of local people in Ejido Ramos Millán to preserve their forests and to prohibit hunting of both species, has promoted environmental conditions (such as abundant food and abundant water) that allow the establishment and reproduction of resident individuals within the northern part of Uxpanapa valley.

\section{Acknowledgements}

We thank J. Salazar Ortiz from Colegio de Postgraduados, Campus Córdoba, and N. Hernández for the loan of some camera traps. We also thank the field support of the inhabitants of Ejido Ramos Millán, specially Alberto, Eleuterio and Abraham García, Ángel, and Z. Gómez and V. Rodríguez. Figure 1 was based on a preliminar illustration elaborated by E. A. López, R. Reyna, and J. L. Peña assisted with the interpretation of the photographs.

\section{Literature cited}

Botello, F., A. G. Romero-Calderón, J. Sánchez-Hernández, 0. Hernández, G. López-Villegas, and V. Sánchez-Cordero. 2017. Population density of Central American tapir (Tapirella bairdii) in cloud forest in Totontepec Villa de Morelos, Oaxaca, Mexico. Revista Mexicana de Biodiversidad 88:918-923.

Briones-Salas, M., I. Lira-Torres, R. Carrera-Treviño, and G. SÁnchez-Rojas. 2016. Relative abundance and activity patterns of wild felids in Chimalapas rainforest, Oaxaca, Mexico. Therya 7:123-134.

Chávez-Tovar, C., J. M. Aranda, and G. Ceballos. 2005. Panthera onca (Linnaeus, 1875). Pp. 367-370 in Los mamíferos silvestres de México (Ceballos, G., and G. Oliva coords.). Fondo de Cultura Económica y Comisión Nacional para el Conocimiento y Uso de la Biodiversidad. Ciudad de México, México.

Chávez-Tovar, C., H. Zarza, J. A. De la Torre, R. A. Medellín, and G. Ceballos. 2016. Distribución y estado de conservación del jaguar en México. Pp. 79-160 in El jaguar en el siglo XXI: la perspectiva continental (Medellín, R., J. De la Torre, H. Zarza, C. Chávez-Tovar, and G. Ceballos, coords.). Fondo de Cultura Económica/ UNAM. Ciudad de México, México.

Ellis, E. A., M. Martínez-Bello, and R. Monroy-lbarra. 2011. Focos Rojos para la Conservación de la Biodiversidad. Pp. 351-367 in La biodiversidad en Veracruz: Estudio de Estado (Comisión Nacional para el Conocimiento y Uso de la Biodiversidad, ed.). CONABIO, Gobierno del Estado de Veracruz, Universidad Veracruzana, Instituto de Ecología, A. C. Veracruz, México.

Espinosa-Reyes, G., C. IlizaliturRi-Hernández, D. González-Mille, J. Mejía-Saavedra, A. D. Nava, M. C. Cuevas, and G. Cilla-López. 2013. Contaminantes orgánicos persistentes en la cuenca baja del río Coatzacoalcos, Veracruz. Pp. 309-322 in Golfo de México. Contaminación e impacto ambiental: diagnóstico y tendencias (Botello, A., J. Rendón von Osten, J. A. Benítez, and G. Gold-Bouchot eds.). UAC, UNAM-ICMYL, CINVESTAVUnidad Mérida. Mérida, México.
García, M., C. Jordan, G. Orfarril, C. Poot, N. Meyer, N. Estrada, R. Leonardo, E. J. Naranjo, Á. Simons, A. Herrera, C. Urgilés, C. Schank, L. Boshoff and M. Ruiz-Galeano. 2016. Tapirus bairdii. IUCN Red List of Threatened Species. http://dx.doi. org/10.2305/IUCN.UK.2016-1.RLTS.T21471A45173340.en

Global Forest Watch. 2018. Forest change and land cover: Interactive map. https://www.globalforestwatch.org/map. Downloaded on December the 5, 2018.

Hernández, G. I., E. A. Ellis, And G. C. Gallo. 2013. Aplicación de teledetección y sistemas de informacion geográfica para el análisis de deforestación y deterioro de selvas tropicales en la región Uxpanapa, Veracruz. Revista Internacional de Ciencia y Tecnología de la Información Geográfica 13:1-24.

LiRa-Torres, I., M. Briones-Salas, AND G. Sánchez-Rojas. 2014. Abundancia relativa, estructura poblacional, preferencia de hábitat y patrones de actividad del tapir centroamericano Tapirus bairdii (Perissodactyla:Tapiridae), en la Selva de Los Chimalapas, Oaxaca, México. Revista de Biología Tropical 62:1407-1419.

Luja, V., C. Navarro, L. A. Torres-Covarrubias, M. CortésHernández, and I. Vallarta. 2017. Small protected areas as stepping-stones for jaguars in western Mexico. Tropical Conservation Science 10:1-8.

March, I., and E. Naranjo. 2005. Tapirus bairdii (Gill, 1865). Pp. 367-370 in Los mamíferos silvestres de México (Ceballos, G., and G. Oliva coords.). Fondo de Cultura Económica y Comisión Nacional para el Conocimiento y Uso de la Biodiversidad. Ciudad de México, México.

Melo, F., V. Arroyo-Rodríguez, L. Fahrig, M. Martinez-Ramos, and M. Tabarelli. 2013. On the hope for biodiversity-friendly tropical landscapes. Trends Ecology and Evolution 28:462-468.

Muench, C., and M. Martínez-Ramos. 2016. Can community protected areas conserve biodiversity in human-modified tropical landscapes? The case of terrestrial mammals in southern Mexico. Tropical Conservation Science 9:178-202.

Naranjo, E. J. 2009. Ecology and conservation of Baird's tapir in Mexico 2009. Tropical Conservation Science 2:140-158.

Naranjo, E. J., S. A. Amador-Alcalá, F. A. Falconi-Briones, and R. Reyna-HuRtado. 2015. Distribución, abundancia y amenazas a las poblaciones de tapir (Tapirus bairsii) y pecarí de labios blancos (Tayassu pecari) en México. Therya 6:227-249.

Quigley, H., R. Foster, L. Petracca, E. Payan, R. Salom, and B. Harmsen. 2017. Panthera onca. IUCN Red List of Threatened Species. http://dx.doi.org/10.2305/IUCN.UK.2017-3.RLTS. T15953A50658693.

Rodríguez-Soto, C., O. Monroy-Vilchis, L. Maiorano, L. Boitani, J. C. Faller, M. A. Briones, R. Núñez, O. Rosas-Rosas, G. Ceballos, ANd A. Falcuccl. 2011. Predicting potential distribution of the jaguar (Panthera onca) in Mexico: identification of priority areas for conservation. Diversity and Distributions 17:350-361.

Secretaría De Medio Ambiente y Recursos Naturales (SEMARNAT). 2009. Programa de Acción para la Conservación de la Especie: Jaguar (Panthera onca). Ciudad de México, México.

Secretaría De Medio Ambiente y Recursos Naturales (SEMARNAT). 2010. Norma Oficial Mexicana NOM-059-SEMARNAT-2010. Protección Ambiental-Especies nativas de México de flora y fauna silvestres-Categorías de riesgo y especificaciones para su inclusión, exclusión o cambio. Lista de especies en riesgo. Ciudad de México, México. 
Associated editor: Rafael Ávila Flores

Submitted: January 27, 2019; Reviewed: February 27, 2019;

Accepted:September 30, 2019; Published on line: January 23, 2020. 